L.A. Karachevtseva ${ }^{1}$, M.T. Kartel ${ }^{2}$, O.O. Lytvynenko ${ }^{1}$

\title{
1D AND 2D POLARITONS IN MACROPOROUS SILICON STRUCTURES WITH NANO-COATINGS
}

\author{
${ }^{1}$ V. Lashkaryov Institute of Semiconductor Physics of National Academy of Sciences of Ukraine \\ 41 Nauki Ave., Kyiv,03028, Ukraine,E-mail: lakar@isp.kiev.ua \\ ${ }^{2}$ Chuiko Institute of Surface Chemistry of National Academy of Sciences of Ukraine \\ 17 General Naumov Str., Kyiv, 03164, Ukraine
}

\begin{abstract}
In this paper, we used high-resolution IR absorption spectra to investigate $1 D$ and $2 D$ polaritons in periodical $2 D$ macroporous silicon structures with nano-coatings of $\mathrm{SiO}_{2}$ and $\mathrm{CdS}, \mathrm{ZnO}$ nanoparticles. The application of highresolution IR absorption spectroscopy resulted in detection of dipole-active TO vibrations, photon splitting and giant two-polar absorption oscillations with amplitudes of $\pm 10^{7}$ arb.un. As a result, the dispersion law in yz surfaces of macropores change to $z$ direction along macropores. It means additional degree of freedom as vertically polarized light in $z$ direction and horizontally polarized light in $x$ direction resulted in beams splitting and two-photon interference - Hong-Ou-Mandel effect. In our case, 2 D resonances of Wannier-Stark electro-optical effect in yz plane correspond to constructive interference of the two-photon states (bosonic behavior), and two-polar resonances in $\pm z$ direction are determined by destructive interference of the two-photon states (fermionic behavior). Two-polar oscillations of $1 D$-polaritons have the ultra-small half-width $0.4-0.6 \mathrm{~cm}^{-1}$ and minimal Rabi frequency of samples $1.0 \mathrm{~cm}^{-1}$ equaled to the resolution of spectral measurements. Furthermore, two-photon interference and $1 D$ polaritons are perspective for high-coherent optical quantum computers on macroporous silicon with nano-coatings and, in addition, for lasers and new metamaterials.
\end{abstract}

Keywords: macroporous silicon, nano-coatings, $1 D$ and $2 D$ polaritons, beams splitting, two-photon interference

\section{INTRODUCTION}

Macroporous silicon structures prepared by photoanodic etching are one of the promising materials for the development of $2 \mathrm{D}$ photonic crystals $[1,2]$ and for the measuring of photonic band gaps [3-6]. Presence of periodically located cylindrical macropores provides large effective macropore surface and enhanced photo-physical characteristics of macroporous silicon [7-9]. Franz-Keldysh oscillations in the electroreflectance spectra of macroporous silicon structures without nanocoatings in the area of direct band-to-band transition were measured [10]. At the wavelengths, compared with the optical period of the macroporous silicon structures, the measured IR absorption is two orders of magnitude higher of the silicon single crystal. The formation of steps and the change in optical absorption by the $3 / 2$ law confirmed realization of the impurity Franz-Keldysh effect [11]. In addition, for 2D macroporous silicon structures with coatings of surface nanocrystals, oscillations of IR absorption increase to maximal amplitudes in the spectral region of surface states [1]. The dependence of the oscillation maxima on its number is linear with a constant period. The analysis of IR absorption oscillations was performed within the model of resonant scattering of electrons on surface states in a strong electric field with a difference between two resonant energies equal to the Wannier-Stark step $\Delta E=F a$ ( $F$ - the electric field strength, and $a$ - the silicon lattice constant) [1]. The shift and deviations of oscillation peaks, the broadening parameter $\Gamma$ of the Wannier-Stark ladders and the influence of "quantum superiority" on coherence of Wannier levels were analyzed in [2]. In addition, we proposed a high coherent optical quantum computer based on a silicon matrix with macropores and a layer of nanocrystals on the macropore surface for the implementation of Wannier-Stark quantum electro-optical effect [12].

In this work, we investigated high-resolution optical absorption spectra of 2D macroporous silicon structures with nano-coatings. We performed a comparative analysis of the results on electro-optical effects in macroporous silicon of 1D and 2D exciton-polaritons on macropores. Here we achieved excellent parameters of 1D 
exciton-polaritons at room temperature for highcoherent optical phenomena implementations in quantum computers, lasers and metamaterials.

\section{PROCEDURE}

The samples to be studied were made of silicon wafers with thickness $H=520 \mu \mathrm{m}$, resistivity of $4.5 \Omega \cdot \mathrm{cm}$, characterized by the (100) orientation and $n$-type of conductivity (the electron concentration $n_{0}=10^{15} \mathrm{~cm}^{-3}$ ). We used the technique of electrochemical etching at the backside illumination of a silicon substrate (thickness $H=520 \mu \mathrm{m}$ ) [13, 14]. Macropores were etched in the form of a square lattice of parallel air cylinders with diameter $D p=2 \pm 0.2 \mu \mathrm{m}$, period $4 \mu \mathrm{m}$, depth $h p=50 \div 100 \mu \mathrm{m}$, and concentration $N p=6.25 \cdot 10^{6} \mathrm{~cm}^{-2}$ (Fig. 1). Addition anisotropy etching in $10 \%$ solution of $\mathrm{KOH}$ permits to remove microporous layers from the macropores surface.

$\mathrm{SiO}_{2}$ nano-coatings were formed in the diffusions to ve after treatment of macroporous silicon substrates in the nitrogen atmosphere [15]. The oxide layers (thickness of 10 and $20 \mathrm{~nm}$ ) were obtained on macroporous silicon samples in dry oxygen during $40 \div 60 \mathrm{~min}$ at the temperature of $1050^{\circ} \mathrm{C}$. The oxide thickness was measured using ellipsometry.

CdS nanoparticles of 1.8-2 nm in size [16] were deposited on the oxidized surface of macropores from the colloidal solutions in polyethyleneimine (PEI). Method of synthesis of $\mathrm{ZnO}$ nanoparticles in isopropanol and from solution of zinc acetate of $\mathrm{Zn}\left(\mathrm{CH}_{3} \mathrm{COO}\right)_{2}$ in ethanol have been developed in [17].

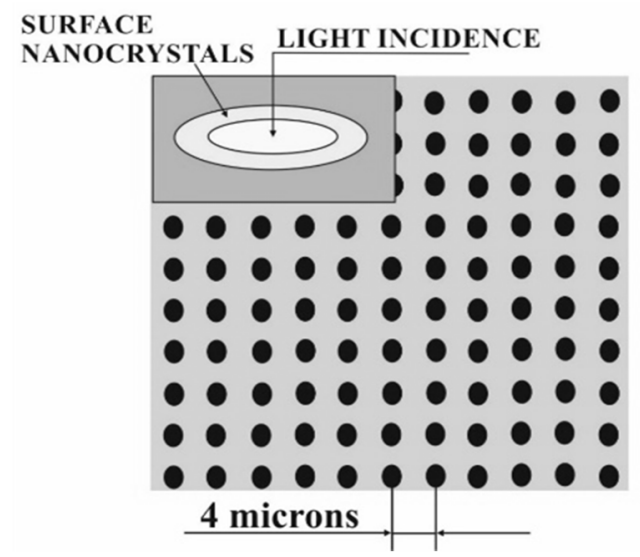

Fig. 1. Scheme of two-dimensional macroporous silicon structures with layer $\mathrm{ncCdS}+\mathrm{SiO}_{2}$; macropore diameter $D_{p}=2 \mu \mathrm{m}$ and period $4 \mu \mathrm{m}$; insertion: normal incidence of IR radiation on a sample (along the pores)

Table shows the parameters of nano-coatings on 2D macroporous silicon structures. We performed optical investigations within the spectral range $300 \ldots 7800 \mathrm{~cm}^{-1}$ by using an IR Fourier spectrometer "PerkinElmer" (Spectrum BXII). High-resolution optical absorption spectra were measured in the $200 \div 8500 \mathrm{~cm}^{-1}$ spectral range on a spectrometer BrukerVertex 70 Vwith a resolution of $1 \mathrm{~cm}^{-1}$.

The optical absorption spectra were measured at normal incidence of IR radiation on a sample (along the cylindrical macropores, Fig. 1, insertion) in the air at room temperature.

Table. The parameters of nano-coatings on 2D macroporous silicon structures and splitting of surface modes

\begin{tabular}{|c|c|c|c|c|c|c|c|}
\hline $\begin{array}{l}\text { No of } \\
\text { sample }\end{array}$ & $\begin{array}{c}\text { Boundary } \\
\text { "Si - nanocoating" }\end{array}$ & $\begin{array}{l}\text { Thickness } \\
d_{1} \text { of } \mathrm{SiO}_{2} \\
\text { layer, } \mathrm{nm}\end{array}$ & $\begin{array}{c}\text { Thickness } \\
d_{2} \text { of "PEI- } \\
\text { Nclayer", } \\
\text { nm } \\
\end{array}$ & $d / \lambda$ & $(d / \lambda)^{1 / 2}$ & $\begin{array}{c}\text { Splitting } \\
\text { of surface } \\
\text { modes, } \\
\text { cm }^{-1} \\
\end{array}$ & $\begin{array}{c}\text { Rabi } \\
\text { frequency } \\
\left(\mathbf{c m}^{-1}\right)\end{array}$ \\
\hline 1 & $\mathrm{Si-} \mathrm{SiO}_{2}+“ P E I-n c C d S "$ & 10 & 16 & $6.25 \cdot 10^{-4}$ & 0.0025 & - & 1.0 \\
\hline 2 & $\mathrm{Si}-\mathrm{SiO}_{2}+" \mathrm{PEI}-\mathrm{ncCdS} "$ & 20 & 16 & $1.25 \cdot 10^{-3}$ & 0.0353 & 6 & 1.0 \\
\hline 3 & $\mathrm{Si}-\mathrm{SiO}_{2}+" \mathrm{PEI}-\mathrm{ncCdS} "$ & 20 & 28 & $3.0 \cdot 10^{-3}$ & 0.055 & 14 & 1.0 \\
\hline 4 & $\mathrm{Si}-\mathrm{SiO}_{2}+" \mathrm{PEI}-\mathrm{ncZnO} "$ & 20 & 28 & - & - & - & 1.0 \\
\hline
\end{tabular}

\section{EXPERIMENT AND DISCUSSION OF RESULTS}

Figures $2 a, b$ show comparison of the absorption spectra of the structure \#1: after changing resolution of measurement from $2 \mathrm{~cm}^{-1}$ (curves 1) to $1 \mathrm{~cm}^{-1}$ (curves 2) the period of oscillations in optical absorption spectra decreases by 3 times and the optical absorption increases by $60-100$ times.

Figures $3 a, b$ shows fragments of IR optical absorption spectra of structure \#1 (Table) with a resolution of $1 \mathrm{~cm}^{-1}$. Giant two-polar oscillations 
of the absorption appear in the spectral region of $\mathrm{Si}-\mathrm{Si}$ bonds and in the $5500-7500 \mathrm{~cm}^{-1}$ spectral region of $P_{\mathrm{b}}$ centers $[15,19]$.

Si-Si-bonds represent the transverse fluctuations of silicon atoms on the surface of the macropores, i.e., transverse phonons [19]. Fig. $3 a$ and Fig. $4 a, b$ show fragments of the absorption spectra of 2D macroporous silicon structures with

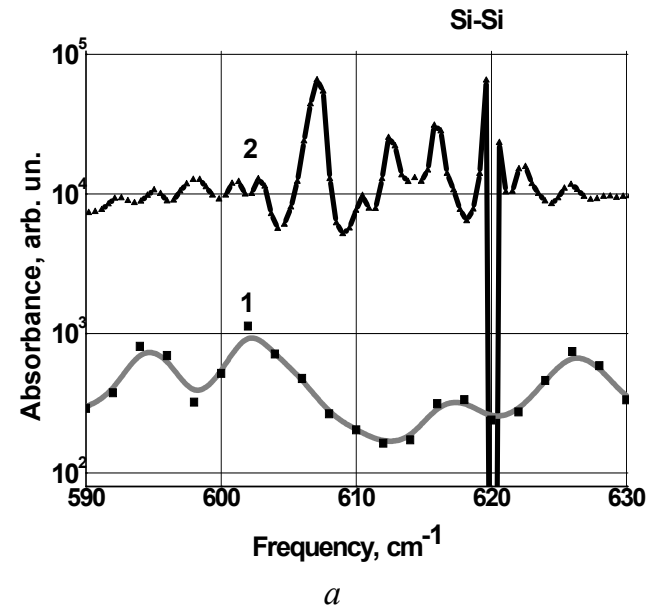

nano-coatings from Table in the spectral region of Si-Si-bonds: Fig. $3 a$ includes one minimum for sample \#1, Fig. 4 a includes two minima for sample \#2, and Fig. $4 b$ includes three minima for sample \#3. Samples \#1 and \#2 differ in the thickness of the $\mathrm{SiO}_{2}$ layer on the macropore surface (Table).

Fig. 2. Fragments of the absorption spectra of the structure \#1 for the resolution of measurements $2 \mathrm{~cm}^{-1}$ (curves 1$)$ and resolution $1 \mathrm{~cm}^{-1}$ (curves 2) in the spectral ranges: $a-590-625 \mathrm{~cm}^{-1} ; b-6130-6150 \mathrm{~cm}^{-1}$

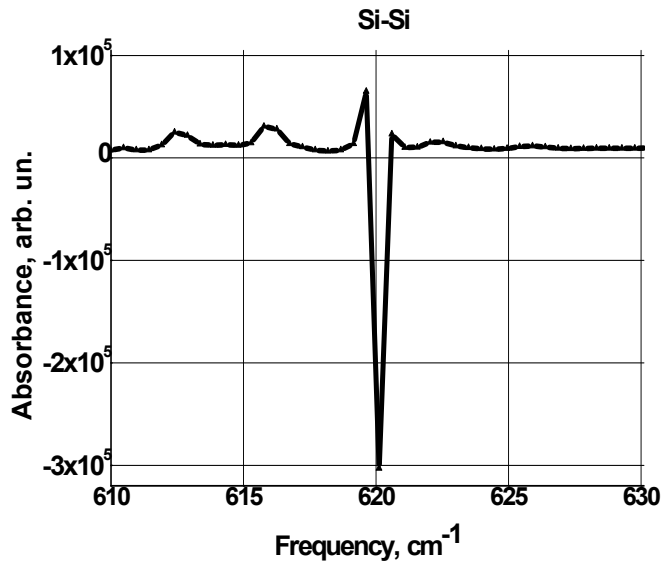

$a$

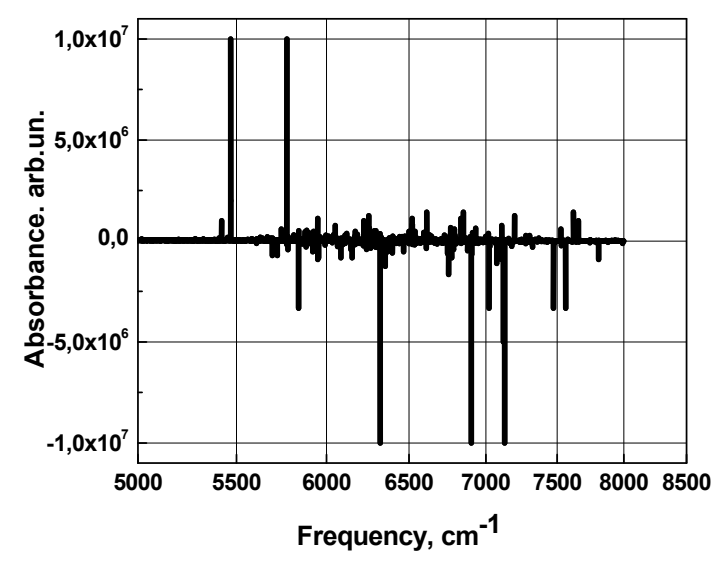

$b$

Fig. 3. The optical absorption by $2 \mathrm{D}$ structures of macroporous silicon with nano-coatings for sample \#1 from Table measured at resolution of $1 \mathrm{~cm}^{-1}: a$-at spectral region of Si-Si-bonds; $b$-at spectral region of $P_{\mathrm{b}}$ centers

At thickness of the $\mathrm{SiO}_{2}$ layer $d_{1}=10 \mathrm{~nm}$ the surface polaritons are formed at the frequency $\omega_{\mathrm{S}}$ (Fig. $3 a$ ) equal to the frequency of transverse phonon $\omega_{\text {TO }}=620 \mathrm{~cm}^{-1}$ [19]. When the $\mathrm{SiO}_{2}$ thickness is $d_{1}=20 \mathrm{~nm}$ on the boundary " $\mathrm{SiO}_{2}-$ macropore surface", the splitting of mode is formed (Fig. $4 a$ ). The thickness of "PEI-ncCdS" layer increase to $d_{2}=28 \mathrm{~nm}$ for sample \#3 (Table). Thus additional modes and the additional surface polaritons are formed for sample \#3 (Fig. 4 b) due to resonance interaction of dipole-active oscillations with surface polaritons.

In general, the interaction of an external electromagnetic field with dipole-active states leads to polariton formation [20, 21]. These resonances lead to the splitting of surface polaritons and to the appearance of the slits in its spectrum with width proportional to $(d / \lambda)^{1 / 2}[20]$. 
Table shows minimal value of $d / \lambda=(0.625-3) \cdot 10^{-3}<<1$ and small splitting of surface polariton modes, equaled to $6-14 \mathrm{~cm}^{-1}$ for structures \#2 and \#3 (Fig. $4 a, b$ ). It is proportional to $\left(d_{2} / d_{3}\right)^{1 / 2}$, where $d_{2}=20 \mathrm{~nm}$ and $d_{3}=20+28=48 \mathrm{~nm}$. So, for 2D macroporous silicon structures with nano-coatings surface

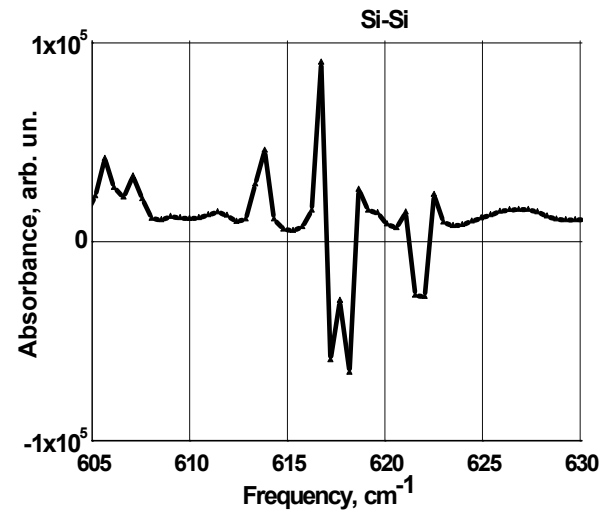

$a$ polaritons are formed at boundary $\mathrm{Si}-\mathrm{SiO}_{2}$ for samples \#1 (Fig. 3 a), and at boundaries $\mathrm{Si}_{-} \mathrm{SiO}_{2}$ and $\mathrm{SiO}_{2}+$ "PEI-ncCdS" for samples \#2 and \#3 (Table), The results obtained are fully consistent with data for phonon polaritons in microresonators [20].

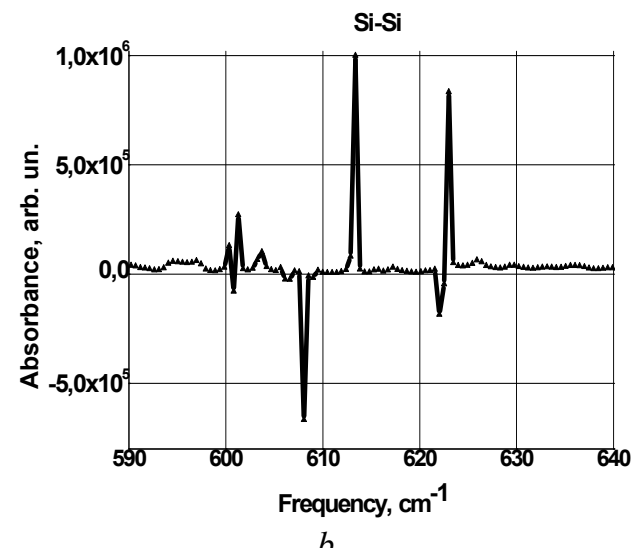

Fig. 4. The optical absorption by $2 \mathrm{D}$ structures of macroporous silicon with nano-coatings: $a$ - sample \#2, $b$ - sample \#3 from Table measured at resolution of $1 \mathrm{~cm}^{-1}$ near Si-Si-bonds

Measurements the giant two-polar oscillations with very small half-width $0.5 \mathrm{~cm}^{-1}$ and Rabi frequency $1.0 \mathrm{~cm}^{-1}$ (Table) testify the strong interaction of surface polaritons with photons. Moreover, by changing the thickness of the nanocoatings, it is possible to achieve a match in the frequency of interference modes with frequencies of slit oscillations of surface bonds on boundaries $\mathrm{Si}_{-} \mathrm{SiO}_{2}$ and $\mathrm{SiO}_{2}+$ "PEI-ncCdS". When the frequencies of local oscillations of surface bonds and slit modes matched, then the light absorption increases up to $10^{5}$ times on the frequencies of slit oscillations of surface bonds [21].

Earlier we observed the oscillating structure in the absorption spectra of macroporous silicon structures with surface nanocrystals $[1,2]$. The form of oscillations and constant oscillation period indicate the resonant character of scattering (the Wannier-Stark electro-optical effect). According to method of experimental observation of Wannier-Stark ladders [22], the scattering amplitude has resonant behavior at electron scattering on impurities.

The wave function in the Wannier representation is:

$\left\langle j \mid \psi_{E}\right\rangle=\left\langle j \mid \Phi_{E}\right\rangle+\frac{\left\langle j\left|\hat{G}_{0}(E)\right| 0\right\rangle V_{0}\left\langle 0 \mid \Phi_{E}\right\rangle}{1-V_{0}\left\langle 0\left|\hat{G}_{0}(E)\right| 0\right\rangle}$
Here the first (second) term describes the incident wave (scattered waves); $j$ - numbers the lattice site, $\hat{G}_{0}(E)$ is the Green operator, $V_{0}$ is the impurity potential. The complex energies of resonances in electron scattering are

$1 / V_{0}=\left\langle 0\left|\hat{G}_{0}(E)\right| 0\right\rangle$

at $E=\varepsilon-i \Gamma(\Gamma>0)$. The difference of two neighboring resonance energies is equaled approximately to the value of the step in the Wannier-Stark ladder. The dispersion law is considered in form:

$E(\kappa)=E_{0}-\Delta\left(\cos k_{y} a+\cos k_{z} a\right)$,

where $k$ is a quasi-momentum with components $k_{y}, k_{z}, E_{0}$ is the energy corresponding to the midgap, $\Delta-$ the energy equal to $1 / 6$ of the band gap, $a-$ Si lattice parameter.

In our case, an electric field of "siliconnanocoating" heterojunctions on the macropore surface is directed perpendicularly to the macropore surface (Fig. 5 a), and surface states that scatter electrons are concentrated perpendicularly to the $x$-direction in the plane $(y, z)$, that is the plane of resonant scattering. After illumination, electrons are accelerated in the 
electric field of the enriched electric potential (Fig. $5 \mathrm{~b}$ ), oscillate and scatter by surface states in the radial direction $x$ relative to the macropore, in the plane $(y, z)$ (Fig. $5 a$ ), which is the plane of resonance scattering with infinity amplitude [22].

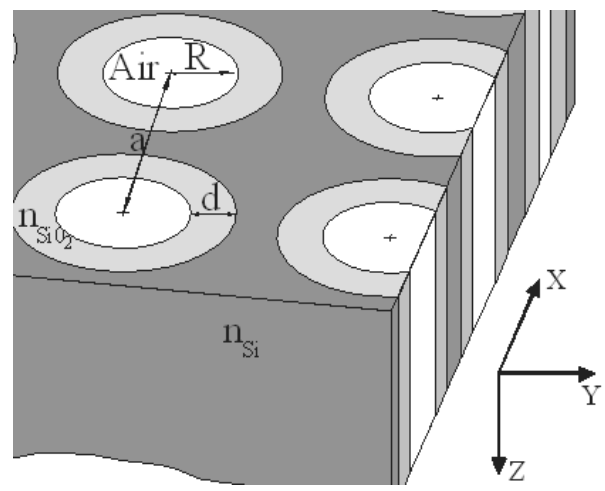

$a$
It results in additional vertically polarized light in $z$ direction and horizontally polarized light in $x$ direction and the infinity growth of dielectric constants and corresponding changes in IR absorption at room temperature.

\section{Input ports $A$ and $B$}

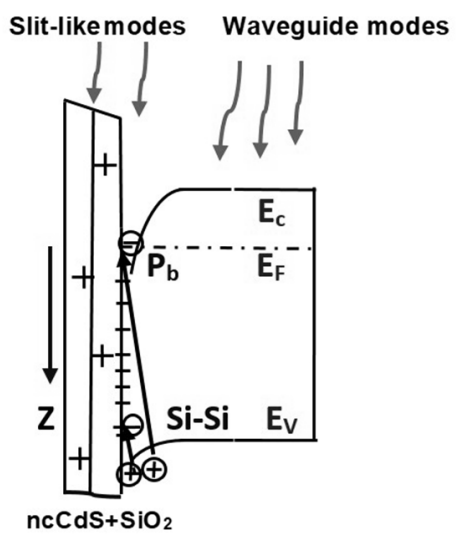

Output ports $C$ and $D$

$b$

Fig. 5. $a-$ a fragment of the macroporous silicon structure with the nanocoating with the radius of macropore $R$ and the surface nanocoating thickness $d ; b$ - beam splitter with input and output ports. Scheme of band bending on the surface of macropores between macroporous silicon matrix with Fermi level $E_{\mathrm{F}}$ and layers ncCdS and $\mathrm{SiO}_{2}$ (circles - electrons and holes, lines - impurity states)

For 2D macroporous silicon structures with nano-coatings, band bendings on the surface of the macropores are significant (Fig. 5 b). Under these conditions, surface polaritons interact with photons strongly $[20,21]$ due to resonances of dipole-active vibrations and surface modes at boundaries $\mathrm{Si}_{-} \mathrm{SiO}_{2}$ and $\mathrm{SiO}_{2}+$ "PEI-ncCdS" on macropores. Shape of oscillations [12] corresponds to the interference of polaritons as the eigenstates of the system "nanocoating silicon matrix - waveguide modes" (Fig. 6). In our case, an additional degree of freedom due to creation of vertically polarized light in $z$ direction and horizontally polarized light in $x$ direction (Fig. $5 a$ ) permit to interpret the obtained result as two-photon interference - Hong-Ou-Mandel effect [23]. In this case, macropore is a beam splitter (BS) with maximum and minimum coincidences for measurements with parallel and perpendicularly polarizations, respectively. Beam splitter includes input ports A and B, and output ports labelled $\mathrm{C}$ and $\mathrm{D}$. The four ways of the two photons can exit from the beam splitter through the same port or different ports. Two-photon states corresponded to photons exiting through the same output ports demonstrate constructive interference (bosonic behavior). The two-photon states corresponding to photons exit through the different output ports demonstrate destructive interference (fermionic behavior).

In case [12], presented in Fig. 6, we observed the "constructive" interference of the two-photon states corresponded to photons exited through the same output ports $\mathrm{C}$ and D (Fig. $5 b$, bosonic behavior). Maximum coincidences for measurements of the IR absorption spectrum of macroporous silicon structures with surface $\mathrm{ZnO}$ nanocrystals (Fig. 6, grey curve 1) and the same spectrum of IR absorption, moved for 2 period (Fig. 6, black curve 2) confirmed the high coherence of "constructive" interference of the two-photon states.

In addition, we measured giant two-polar oscillations of the absorption in spectra of Fig. 4 and Fig. 5 at TO-vibrations of Si-Si-bonds [24] and $P_{\mathrm{b}}$ centers [25]. Interaction of TO phonons with the scattered electrons in $z$ direction (Fig. $5 b$ ) enhances $k_{z}$ - vibrations, and the 
dispersion law (3) transforms to $E(\kappa)=E_{0}-\Delta\left(\cos k_{z} a\right)$. Amplitude of the resonance scattering became dependent on the secant function $\left(\cos k_{z} a\right)^{-1}=\sec k_{z} a$ ), and the slitlike modes $[28,29]$ are formed on boundaries "silicon matrix - nanocoatings". Fig. $7 a-d$ show fragments of optical absorption from Fig. $3 b$ for sample \#1 and a resolution of $1 \mathrm{~cm}^{-1}: a-$ in spectral area of $P_{\mathrm{b}}$ centers; $b$ - theoretical calculations the secant function, and $c, d-$ fragments of optical absorption spectra $a$ and $b$ enlarged on the $y$ axis. Fig. $7 a-d$ confirms qualitatively the model of the two-polar giant oscillations in optical absorption spectra depended on the function $\sec k_{z} a$. In this case, the two-photon waves exit from the beam splitter through the different ports, and we observe destructive interference of the two-photon states corresponding to fermionic behavior of two-polar oscillations.

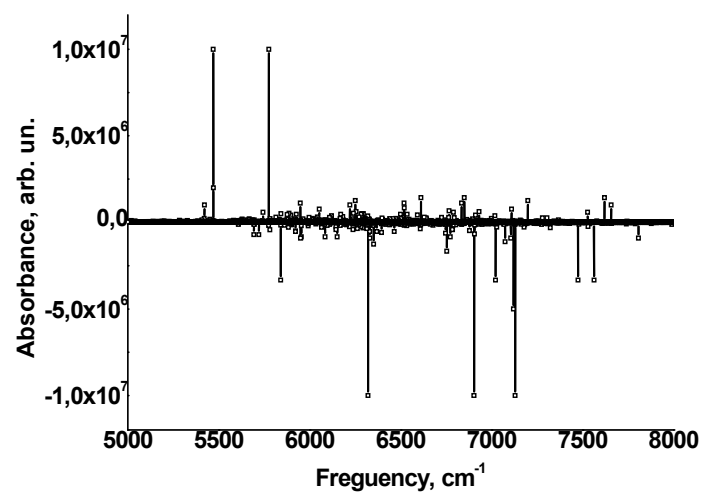

$a$

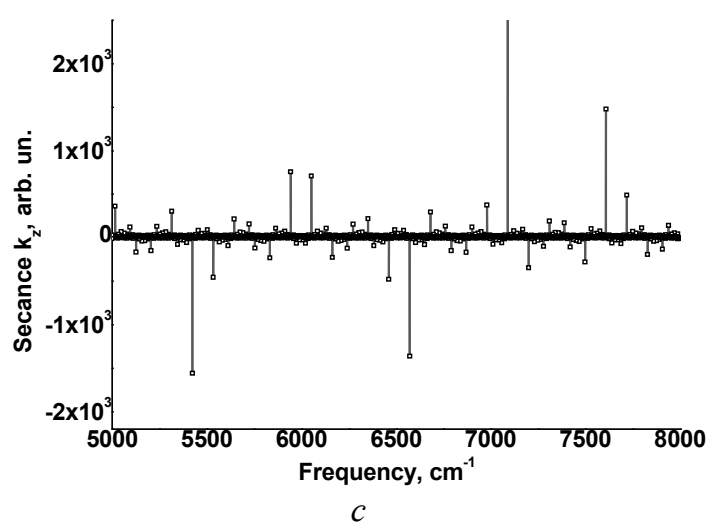

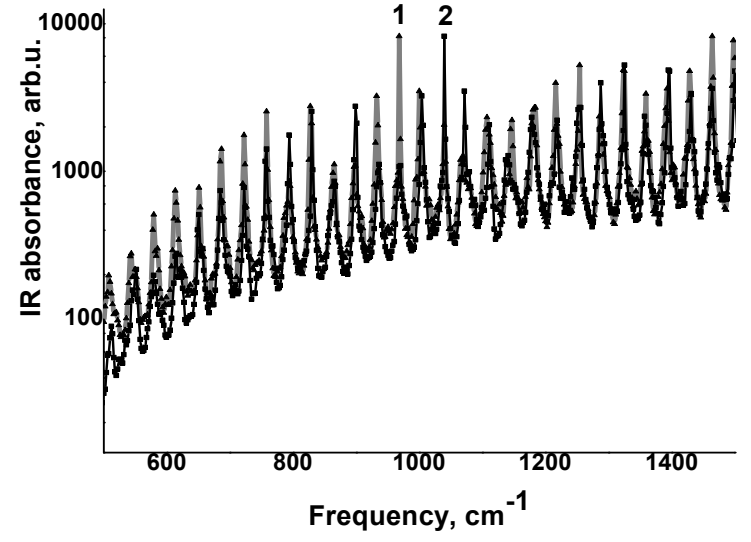

Fig. 6. Dependences of the IR absorption of macroporous silicon structures with surface $\mathrm{ZnO}$ nanocrystals (structure \#4) in the spectral range $500-1500 \mathrm{~cm}^{-1}(1)$, the same spectrum of IR absorption, moved for 2 period (2)
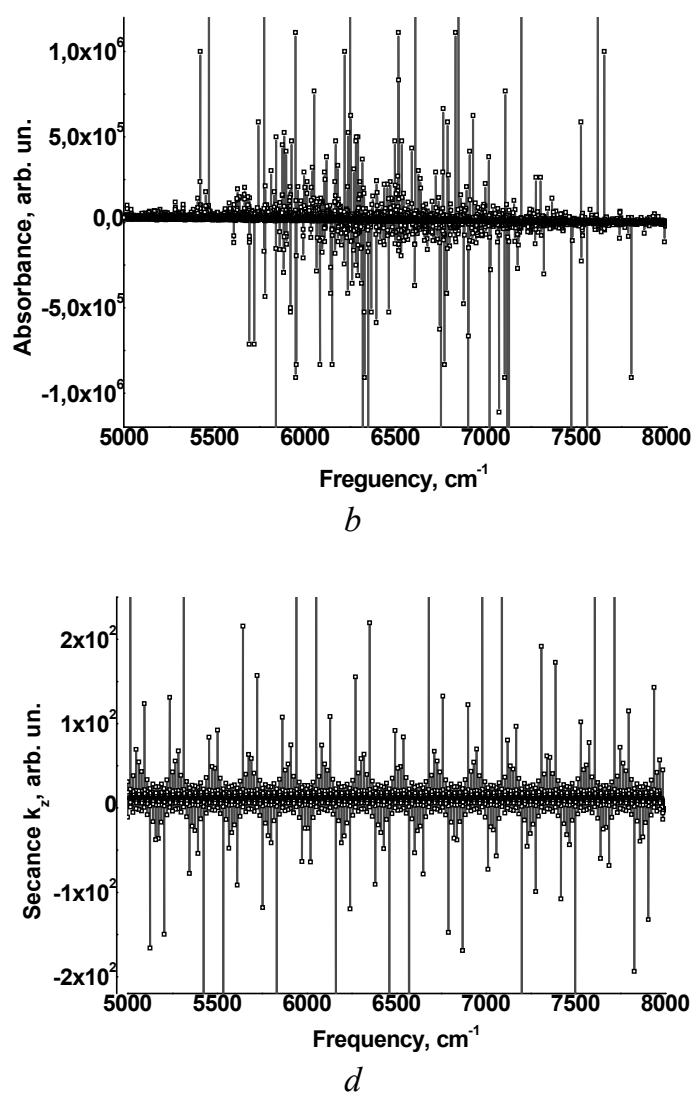

Fig. 7. Fragments of optical absorption of sample $\# 1$ measured with a resolution of $1 \mathrm{~cm}^{-1}$ in spectral area $5000-8000 \mathrm{~cm}^{-1}$ of $P_{\mathrm{b}}$ centers $(a) ; b$ - theoretical calculations by the secant function; $(c),(d)$ - fragments of optical absorption spectra $(a)$ and $(b)$ with reduced $y$ axi 
It means that 2D resonances of Wannier-Stark electro-optical effect in $y z$ plane (Fig. 6) transforms into 1D resonances in one direction $z$ of surface waves (Fig. 7) and into the onedimensional (1D) polaritons. Such transformation results in the giant amplitudes of absorption oscillations ( $\pm 10^{7}$ arb. un.) and measurements the ultra-small half-width of oscillations $\left(0.5 \pm 0.1 \mathrm{~cm}^{-1}\right)$ and minimal Rabi frequency of samples $\left(1.0 \mathrm{~cm}^{-1}\right)$ equaled to resolution of spectral measurement (Table).

The quantum statistics of atoms is observed typically in the behavior of an ensemble via macroscopic observables, in addition, quantum statistics modifies the behavior of even two particles. The basis of the two-photon interaction provides the mixing between the two input modes via the action of the beam splitter (BS) [23] with the diagonal coherent state representation; in particular, they give the explicit example of what happens when two photons, one horizontally and one vertically polarized, are incident from different input ports. In this case, one observe constructive interference of the two-photon states corresponding to photons exiting through the same output ports (bosonic behavior), and destructive interference of the two-photon states corresponding to photons exiting opposite output ports (fermionic behavior). So far, two-particle interference has been investigated on massive particles, such as electrons, atoms, plasmons, and more complex quantum systems [24].

In our case, 2D resonances of Wannier-Stark electro-optical effect in $y z$ plane correspond to constructive interference of the two-photon states (bosonic behavior, 2D polaritons), and two-polar resonances in $\pm z$ direction are determined by 1D polaritons (destructive interference of the twophoton states, fermionic behavior).

\section{CONCLUSIONS}

1D polaritons with the giant two-polar oscillations in IR absorption spectra of macroporous silicon with nano-coatings were measured. The generated photoelectrons link heavily with holes in the macropore potential pits forming 2D interference polaritons at room temperature. Increase the resolution of IR spectra measurements to $1 \mathrm{~cm}^{-1}$ resulted in generation of dipole-active vibrations and change of dispersion law in $y z$ plane of macropore surface to $z$ direction along macropores. Thus, 2D polariton transforms into $1 \mathrm{D}$ polariton according to secant law in spectral area of TO-vibrations of Si-Si-bonds and $P_{\mathrm{b}}$ centers.

Surface polaritons interact with photons strongly due to resonances of dipole-active vibrations and surface modes at boundaries $\mathrm{Si}-\mathrm{SiO}_{2}$ and $\mathrm{SiO}_{2}+$ "PEI-ncCdS" on macropores. Shape of oscillations corresponds to the interference of polaritons as the eigenstates of the system "nanocoating - silicon matrix waveguide modes". In our case, the vertically polarized light along macropores ( $z$ direction) and horizontally polarized light ( $x$ direction) permit the explanation of results as two-photon interference (the Hong-Ou-Mandel effect). In this case, macropore is a beam splitter (BS) with maximum and minimum coincidences for measurements with parallel and perpendicularly polarizations, respectively. Beam splitter includes input ports $\mathrm{A}$ and $\mathrm{B}$, and output ports labelled $\mathrm{C}$ and $\mathrm{D}$. The four ways of the two photons can exit from the beam splitter through the same port or different ports. We observedconstructive interference of the twophoton states corresponding to photons exiting through the same output ports (bosonic behavior).Furthermore, 1D polaritons are perspective for high-coherent optical quantum computers on macroporous silicon with nanocoatings, for lasers and new metamaterials. 


\title{
1D та 2D поляритони в структурах макропористого кремнію з нанопокриттями
}

\author{
Л.А. Карачевцева, М.Т. Картель, О.О. Литвиненко \\ Інститут фізики напівпровідників ім. В.С. Лашкарьова Наџіональної академї наук Украӥни \\ пр. Науки, 41, Київ, 03028, Украӥна, lakar@isp.kiev.иа \\ Інститут хімії поверхні ім. О.О. Чуйка Національної академії наук Украӥни \\ вул. Генерала Наумова, 17, Київ, 03164, Украӥна
}

\begin{abstract}
У даній роботі ми використали високо-роздільне IЧ поглинання для дослідження $1 D$ та 2D поляритонів в періодичних структурах макропористого кремнію з нанопокриттями $\mathrm{SiO}_{2}$ та наночастинок $\mathrm{CdS}$, ZnO. IЧ поглинання з високою роздільною здатністю призводить до генерації дипольно-активних поперечних коливань, розщеплення фотонів і вимірювання гігантських двополярних осциляцій поглинання з амплітудами $\pm 10^{7}$ відн.од. Це означає додатковий ступінь свободи, оскільки вертикально поляризоване світло в напрямку z $i$ горизонтально поляризоване світло в напрямку х призводить до розщеплення променів $i$ до двофотонної інтерферениї-ефекту Хонг-Оу-Менделя. В нашому випадку $2 D$ резонанси електро-оптичного ефекту ВаньєШтарка у площчині уz відповідають «конструктивній» інтерферениії двофотонних станів (бозони, 2D поляритони), а двополярні резонанси у $\pm z$ напрямках визначаються «деструктивною» інтерференцією двофотонних станів (ферміони, $1 D$ поляритони). 1D-поляритони є перспективними для високо когерентних оптичних квантових комп'ютерів на основі макропористого кремнію з нанопокриттями, для лазерів $і$ нових метаматеріалів.
\end{abstract}

Ключові слова: макропористий кремній, нанопокриття, $1 D$ та $2 D$ поляритони, двофотонна інтерференція

\section{REFERENCES}

1. Karachevtseva L., Kuchmii S., Lytvynenko O., Sizov F., Stronska O., Stroyuk A. Oscillations of light absorption in 2D macroporous silicon structures with surface nanocoatings. Appl. Surf. Sci. 2011. 257(8): 3331.

2. Karachevtseva L.A. Coherent oscillations in IR spectra of $2 \mathrm{D}$ macroporous silicon structures with surface nanocoatings. Him. Fiz. Tehnol. Poverhni. 2020. 11(1): 115.

3. Karachevtseva L.A., Litvinenko O.A., Stronskaya E.I. Influence of Electrochemical parameters on the etching of macropores in silicon. Theor. Exp. Chem. 2003. 39: 385.

4. Birner A., Wehrspohn R.B., Gösele U.M., Busch K. Silicon-based photonic crystals. Adv. Mater. 2001. 13(6): 377.

5. Karachevtseva L.A. Two-dimensional photonic crystals as perspective materials of modern nanoelectronics. Semiconductor Physics Quantum Electronics and Optoelectronics. 2004. 7(4): 430.

6. Karachevtseva L.A., Karas' N.I., Onischenko V.F., Sizov F.F. Surface polaritons in 2D macroporous silicon structures. Int. J. Nanotechnology. 2006. 3(1): 76.

7. Karachevtseva L.A., Glushko A.E., Ivanov V.I., Lytvynenko O.O., Onishchenko V.F., Parshin K.A., Stronska O.J. Out-of-plane optical transmittance of 2D photonic macroporous silicon structures. Semiconductor Physics, Quantum Electronics \& Optoelectronics. 2007. 10(2): 51.

8. Glushko A., Karachevtseva L. Photonic band structure of oxidized macroporous silicon. Opto-Electron. Rev. 2006. 14: 201.

9. Glushko A., Karachevtseva L. PBG properties of three-component 2D photonic crystals. Photonics Nanostruct. Fundam. Appl. 2006. 4(3):141.

10. Holiney R.Yu., Matveeva L.A., Venger E.F., Karachevtseva L.A., Lytvynenko O.A. Electroreflectance study of macroporous silicon surfaces. Appl. Surf. Sci. 2001. 172(3-4): 214.

11. Karachevtseva L.A., Ivanov V.I., Lytvynenko O.O., Parshin K.A., Stronska O.J. The impurity Franz-Keldysh effect in 2D photonic macroporous silicon structures. Appl. Surf. Sci. 2008. 255(5): 332.

12. Patent UA 136455. Karachevtseva L. Method for Manufacturing of Optical Quantum Computer. 2019.

13. Lehman V. The physics of macropore formation in low doped $n$-type silicon. J. Electrochem. Soc. 1993. 140(10): 2836.

14. Karachevtseva L.A., Litvinenko O.A., Malovichko E.A. Stabilization of electrochemical formation of macropores in n-Si. Theor. Exp. Chem. 1998. 34: 287. 
15. Karachevtseva L., Kartel M., Kladko V., Gudymenko O., Bo Wang, Bratus V., Lytvynenko O., Onyshchenko V., Stronska O. Functionalization of 2D macroporous silicon under the high-pressure oxidation. Appl. Surf. Sci. 2018. 434: 142.

16. Mao J., Yao J.-N., Wang L.-N., Liu W.-S. Easily prepared high-quantum-yield CdS quantum dots in water using hyperbranched polyethylenimine as modifier. J. Colloid Interface Sci. 2008. 319(1): 353.

17. Stroyuk A.L., Shvalagin V.V., Kuchmii S.Ya. Photochemical synthesis and optical properties of binary and ternary metal-semiconductor composites based on zinc oxide nanoparticles. J. Photochem. Photobiol. A. 2005. 173(2): 185.

18. Karachevtseva L., Kuchmii S., Stroyuk A., Sapelnikova O., Lytvynenko O., Stronska O., Bo Wang, Kartel M. Light-emitting structures of CdS nanocrystals in oxidized macroporous silicon. Appl. Surf. Sci. 2016. 388 : 288.

19. Gerardi G.J., Poindexter E.H., Caplan P.J., Jonhson N.M. Interface traps and $P_{\mathrm{b}}$ centers in oxidized (100) silicon wafers. Appl. Phys. Lett. 1986. 49(6): 348.

20. Vinogradov E.A. Semiconductor microcavity polaritons. Physics-Uspekhi. 2002. 45(12): 1213.

21. Vinogradov E.A., Zhizhin G.N., Yakovlev V.A. Resonance between dipole oscillations of atoms and interference modes in crystalline films. J. Exp. Theor. Phys. 1979. 50: 486.

22. Berezhkovskii A.M., Ovchinnikov A.A. Influence of impurities on the Wannier-Stark ladder in semiconductor in a strong electric field. Phys. Stat. Sol. (b). 1982. 110: 455.

23. Ou Z., Hong C., Mandel L. Relation between input and output states for a beam splitter. Opt. Commun. 1987. 63(2): 118 .

24. Heeres R.W., Kouwenhoven L.P., Zwiller V. Quantum interference in plasmonic circuits. Nat. Nanotechnol. 2013. 8: 719 . 